\title{
The Photocatalytic Effect for Decomposition of the Organic Matter in Zr-Ce Composite Oxide under the Visible Rays
}

\author{
Takayuki Kohiruimaki and Ayano Toda* \\ Department of Technology, Hachinohe Institute of Technology, 88-1, Myo Ohbiraki, Hachinohe city 031-8501, Japan \\ Fax: 81-178-25-6825, e-mail: kohi@hi-tech.ac.jp \\ *Graduate School of Science and Technology, Niigata University, 8050, Ikarashi 2-no-cho, Niigata City 950-2181, Japan \\ Fax: 81-25-262-7001, e-mail: f08b070e@mail.cc.niigata-u.ac.jp
}

\begin{abstract}
$\mathrm{Zr}$-Ce composite oxides were synthesized by the combination methods of homogeneous precipitation and sintering. Granular $\mathrm{Zr}$-Ce composite oxide particles with mean diameter of $3 \mu \mathrm{m}$, having high photocatalytic ability under the visible ray, were synthesized when the sintering temperature was $400^{\circ} \mathrm{C}$. The methylene blue decomposition ability higher than $\mathrm{TiO}_{2}$ was confirmed by comparing the reactions under the fluorescent lamp and in the dark place. It may be caused by both the photocatalysis and the adsorption of $\mathrm{Zr}$-Ce composite oxides. The high effectiveness was found also for the decomposition of the following organic substances; methylene blue, cooking oil, surfactant, and whey protein.
\end{abstract}

Key Words: Photocatalyst, Zr-Ce Composite Oxides, homogeneous precipitation, Visible Rays, Decomposition of The Organic Matter

\section{INTRODUCTION}

The photocatalysts, such as titanium oxide, transform the light energy into the oxidation-reduction power. It is strong enough to oxidize and decompose organic materials. Although octahedrite(anatase)-type titanium oxide absorbs only the ultraviolet light (UV) less than $\lambda=400 \mathrm{~nm}^{1,2)}$. Zr-Ce composite oxides are known to show the photocatalytic activity under the visible light. Some studies have been made on the decomposition of organic substances utilizing $\mathrm{Zr}$-Ce composite oxides. They concluded that the effect of decomposition in $\mathrm{Zr}-\mathrm{Ce}$ composite oxide was inferior to titanium oxide ${ }^{3)}$. In this study, $\mathrm{Zr}$ and $\mathrm{Ce}$ composite oxide was noted as the photocatalyst which was superior to titanium oxide in the ability to absorb the visible ray in the wavelength range from 400 to $600 \mathrm{~nm}$. The $\mathrm{Zr} / \mathrm{Ce}$ atomic ratio in the composite oxide and the temperature of heat treatment during the synthesis were optimized to improve the ability for the photolysis of methylene blue. Furthermore, the ability to decompose the organic materials, including the water pollutants, under the fluorescent lamp irradiation was compared with those of titanium oxide.

\section{EXPERIMENTAL}

\subsection{Synthesis of $\mathrm{Zr}$-Ce Composite Oxides}

$\mathrm{Zr}-\mathrm{Ce}$ composite oxides were synthesized by the method combining the homogeneous precipitation and the sintering. For the homogeneous precipitation, zirconyl nitrate and cerium chloride were used as $\mathrm{Zr}$ and $\mathrm{Ce}$ sources, respectively. Two kinds of precipitants were used. The one of them was the solution of $0.83 \mathrm{~mol} \cdot \mathrm{dm}^{-3}$ urea, of which synthetic conditions are shown in Table I. Another one is a mixed aqueous solutions of $0.217 \mathrm{~mol}$. $\mathrm{dm}^{-3} \mathrm{~K}_{2} \mathrm{CO}_{3}$ and $1.76 \mathrm{~mol} \cdot \mathrm{dm}^{-3} \mathrm{H}_{2} \mathrm{O}_{2}$, of which synthetic conditions are listed in Table II. The $\mathrm{Zr} / \mathrm{Ce}$ molar ratio of the composite oxides has been changed in the range from 0.0 to 10 and the totally 10 kinds of samples with the different $\mathrm{Zr} / \mathrm{Ce}$ molar ratio were prepared. To start with, the precursors consisted of amorphous hydroxides or carbonates were precipitated from the mixed solution kept at $98^{\circ} \mathrm{C}$ and then stirred for 24 hours. Next, the obtained precursors were washed with distilled water, and dried in a vacuum desiccator. Lastly, Zr-Ce composite oxides were synthesized by heat-treating at high temperature in the range from 400 to $1000^{\circ} \mathrm{C}$ for one hour ${ }^{4)}$. The structures of these oxides were analyzed by X-ray diffraction and SEM. X-ray powder diffraction patterns were measured using RIGAKU-RINT2100V diffractometer, using $\mathrm{Cu}-\mathrm{K} \alpha$ radiation $(40 \mathrm{kV}, 20 \mathrm{~mA})$. The formation of the solid solution was confirmed from the compositional dependence of lattice parameters. The optical absorption spectra were analyzed by integrating sphere optical system JASCO ISV-469 on UV/VIS spectrophotometer.

\subsection{Decomposition of Some Organic Matters}

The reactivity of the $\mathrm{Zr}$-Ce composite oxide was evaluated by methylene blue. In the $20 \mathrm{ml}$ of $2 \%$ methylene blue solution, $0.25 \mathrm{~g}$ of $\mathrm{Zr}$-Ce composite oxide was suspended and the suspension was kept in a $10 \mathrm{~cm} \phi$ laboratory dish. Those suspensions were irradiated using a $27 \mathrm{~W}$ fluorescent lamp in a dark box. Their absorbance was measured every 24 hours using an absorptiometer, JASCO V-550. The absorbance of those suspensions was also measured without the fluorescent lamp irradiated in a dark box.

Furthermore, some organic substances were decomposed in the $\mathrm{Zr}$-Ce composite oxide suspensions under the fluorescent lamp irradiation. The aqueous solution of organic substances were prepared with the 
Table I. Synthetic conditions of the homogeneous precipitation when urea is used as precipitant.

\begin{tabular}{|c|c|c|c|c|c|c|}
\hline & \multirow{2}{*}{$\begin{array}{c}\text { Sample } \\
\text { No. }\end{array}$} & \multirow{2}{*}{$\begin{array}{c}\mathrm{Zr} / \mathrm{Ce} \\
\text { molar ratio }\end{array}$} & Zr source & Ce source & precipitant & \multirow{2}{*}{$\begin{array}{r}\text { Whole } \\
\text { amount }\end{array}$} \\
\hline & & & $\mathrm{ZrO}\left(\mathrm{NO}_{3}\right)_{2}$ & $\mathrm{CeCl}_{3}$ & Urea & \\
\hline \multirow{2}{*}{ Mono } & $\mathrm{K}$ & $10 / 0$ & $0.020 \mathrm{~mol}$ & $0.0 \mathrm{~mol}$ & \multirow{5}{*}{$5.0 \mathrm{~g}$} & \multirow{5}{*}{$100 \mathrm{ml}$} \\
\hline & $\mathrm{L}$ & $0 / 10$ & $0.0 \mathrm{~mol}$ & $0.020 \mathrm{~mol}$ & & \\
\hline \multirow{3}{*}{ Mix } & M & $5 / 5$ & $0.010 \mathrm{~mol}$ & $0.010 \mathrm{~mol}$ & & \\
\hline & $\mathrm{N}$ & $4 / 6$ & $0.008 \mathrm{~mol}$ & $0.012 \mathrm{~mol}$ & & \\
\hline & $\mathrm{O}$ & $3 / 7$ & $0.006 \mathrm{~mol}$ & $\mid 0.014 \mathrm{~mol}$ & & \\
\hline
\end{tabular}

Table II. Synthetic conditions of the homogeneous precipitation when a mixed solution of $\mathrm{K}_{2} \mathrm{CO}_{3}$ and $\mathrm{H}_{2} \mathrm{O}_{2}$ is used as precipitant.

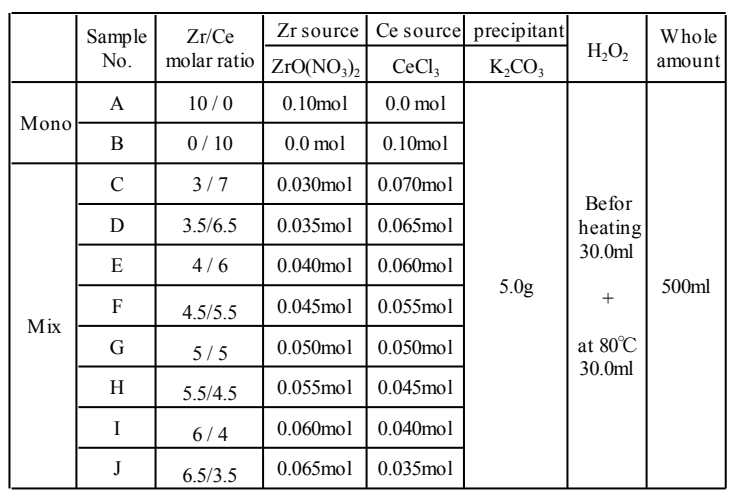

following initial concentration: $\mathrm{COD}$ value of $11.2 \mathrm{ppmO}$ for cooking oil, COD value of 2.4 ppmO for surfactant, and $35 \mathrm{~g} \cdot \mathrm{dm}^{-3}$ for whey protein. In the $20 \mathrm{ml}$ aqueous solution of those organic substances, $1.0 \mathrm{~g} \mathrm{Zr-Ce}$ composite oxides were suspended and the suspension was kept in a $10 \mathrm{~cm} \phi$ laboratory dish. Those solutions were irradiated using a $27 \mathrm{~W}$ fluorescent lamp in the dark box. The COD values of those solutions were analyzed by permanganate titration every 24 hours. Whey protein solution was diluted 1,000 times before COD analysis.

\section{RESULTS AND DISCUSSION}

\subsection{Synthesis of Zr-Ce Composite Oxide}

We investigated the change in the crystal morphology with the temperature of heat treatment. Figure 1 shows SEM pictures in the order of heating temperature for crushed $\mathrm{Zr}-\mathrm{Ce}$ composite oxide samples. $\mathrm{Zr}-\mathrm{Ce}$ composite oxides show granular shape with the diameter in the range of from 2 to $4 \mu \mathrm{m}$. The diameter of the oxides was decreased with decreasing heating temperature. The color of the composite oxides is changed from white to dark yellow with decreasing the heating temperature. At lower temperatures, it is suggested that the particles are loosely sintered and the oxygen composition is depleted.

$\mathrm{X}$-ray diffraction patterns of the $\mathrm{Zr}-\mathrm{Ce}$ composite oxides heat-treated at $400^{\circ} \mathrm{C}$ and with the nominal $\mathrm{Zr} / \mathrm{Ce}$ molar ratio of 10/0, 6/4, 5/5 and 0/10 are shown in Fig. 2. They can be indexed as those of fluorite-type structure ${ }^{5,6)}$ and the peaks show gradual shift with the nominal composition, which means the formation of solid solutions.
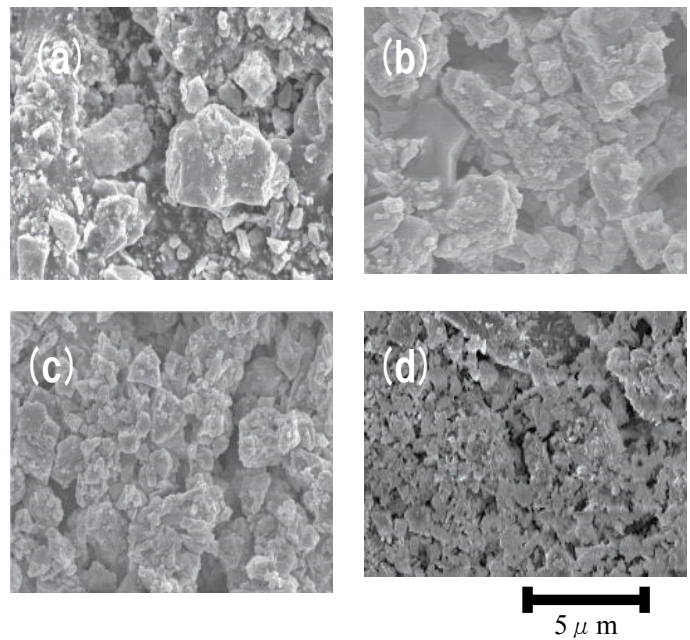

Fig. 1 SEM images of precipitates heat treated at (a) $800^{\circ} \mathrm{C},(\mathrm{b}) 700^{\circ} \mathrm{C},(\mathrm{c}) 600^{\circ} \mathrm{C}$, (d) $400^{\circ} \mathrm{C}$.

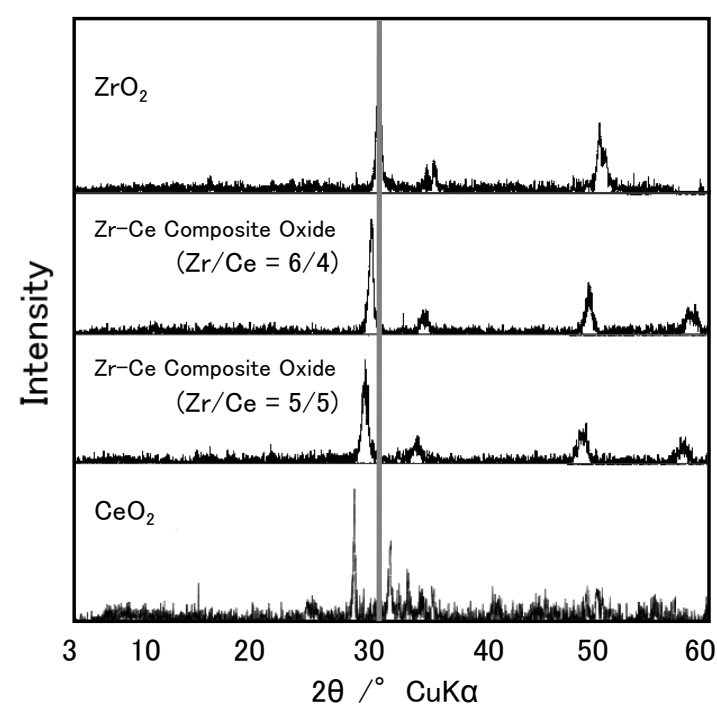

Fig. 2 Powder XRD patterns of samples heat-treated at $400^{\circ} \mathrm{C}$.

The optical absorption spectra of these oxides are shown in Fig. 3. The spectra of $\mathrm{Zr}$-Ce composite oxides show the absorption edge shift to the longer wavelength side up to $500 \mathrm{~nm}$. This observation agrees with the yellow color of $\mathrm{Zr}_{0.5} \mathrm{Ce}_{0.5} \mathrm{O}_{2}$ heat-treated at $400^{\circ} \mathrm{C}$.

\subsection{Decomposition of Some Organic Substances}

We investigated the decomposition of some organic substances in the $\mathrm{Zr}$-Ce composite oxide suspensions under the fluorescent lamp irradiation. First of all, the methylene blue decomposition ability of $\mathrm{Zr}$-Ce composite oxides was compared under the fluorescent lamp irradiation and in the dark place. The time dependences of the optical absorbance by methylen blue under the fluorescent lamp irradiation are shown in Fig. 4, for several suspensions with different $\mathrm{Zr} / \mathrm{Ce}$ molar ratios. The vertical axis shows the absorbance for $\lambda=660 \mathrm{~nm}$. 


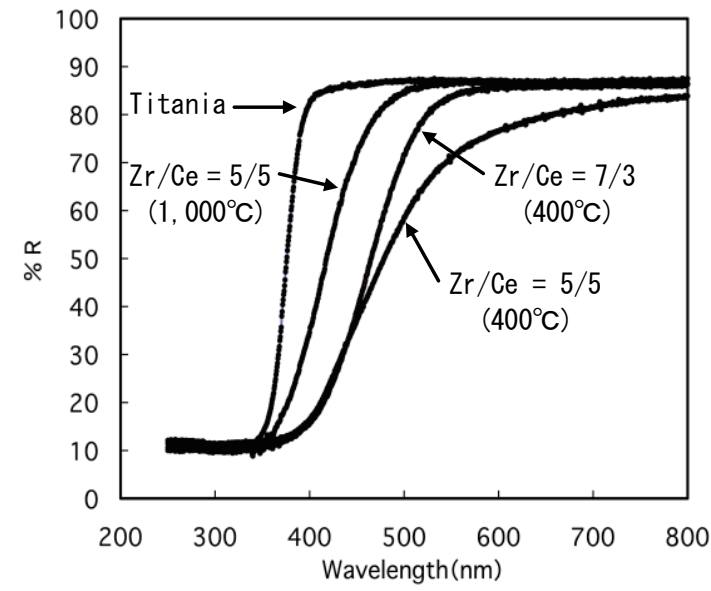

Fig. 3 Optical absorption spectra of typical samples compared with the one of $\mathrm{TiO}_{2}$.

The decrease of the absorbance means the decomposition of methylene blue due to the catalytic activity of the suspensions. The suspensions containing the $\mathrm{Zr}-\mathrm{Ce}$ composite oxides with $\mathrm{Zr} / \mathrm{Ce}$ molar ratio of $5 / 5,4 / 6$ and $3 / 7$ showed the remarkable decrease within 24 hours, compared to $\mathrm{ZrO}_{2}$ and $\mathrm{TiO}_{2}$ suspensions. The time dependences of the absorbance in the dark place are shown in Fig. 5. The decrease of the absorbance was observed for all the suspensions, because of the adsorption of methylene blue on the surface of the oxide fine particles. The $\mathrm{Zr}$-Ce composite oxides with higher Ce content showed the steep decrease. However, when compared with Fig. 4, the effect of the photo-irradiation is prominent for $\mathrm{Zr}$-Ce composite oxides. These results made it clear that the ability of $\mathrm{Zr}$-Ce composite oxides to decompose methylene blue was higher than anatase form titanium oxide both in the effects of the photocatalyst and the adsorption. The $\mathrm{Zr}-\mathrm{Ce}$ composite oxide with the composition of $\mathrm{Zr}_{0.5} \mathrm{Ce}_{0.5} \mathrm{O}_{2}$, which did not show remarkable adsorption ability, seems to be superior in the ability of photocatalysis.

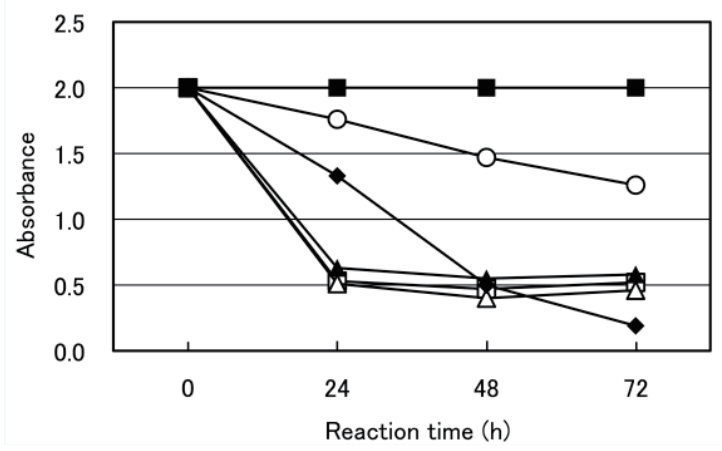

Fig. 4 Time dependences of the optical absorbance by methylene blue in the $\mathrm{Zr}$-Ce composite oxide suspensions under the fluorescent lamp irradiation.

$\mathrm{Zr} /$ Ce molar ratio; $\bigcirc: 10 / 0, \triangle: 5 / 5, \boldsymbol{\Delta}: 4 / 6$,

$\mathbf{\square}$ : without oxides, $\bullet$ : $\mathrm{TiO}_{2}$ for comparison

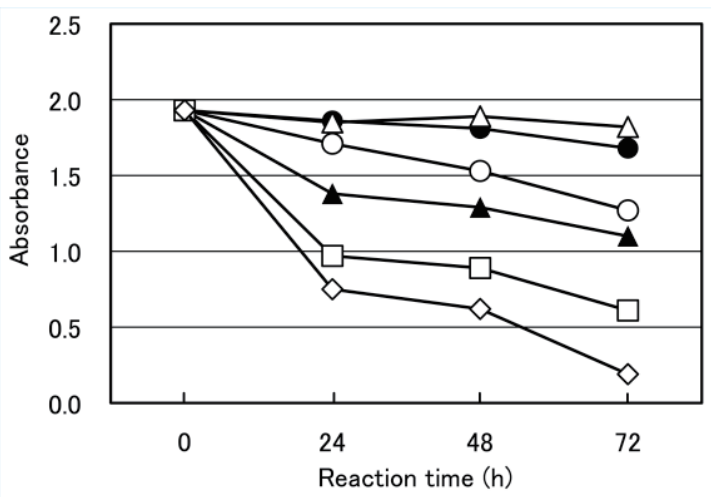

Fig. 5 Time dependences of the optical absorbance by methylene blue in the $\mathrm{Zr}$-Ce composite oxide suspensions without the fluorescent lamp irradiation in a dark box.

$\mathrm{Zr} / \mathrm{Ce}$ molar ratio; $\bigcirc: 10 / 0, \bigcirc: 6 / 4, \triangle: 5 / 5$,

$\boldsymbol{\Delta}: 4 / 6, \square: 3 / 7, \diamond: 0 / 10$

Next, other organic substances in aqueous solutions were decomposed by $\mathrm{Zr}$-Ce composite oxides under the fluorescent lamp irradiation. The time dependence of $\mathrm{COD}$ in the surfactant and $\mathrm{Zr}-\mathrm{Ce}$ composite oxide suspensions under the fluorescent lamp irradiation was shown in Fig. 6. The time dependence of COD in the cooking oil and $\mathrm{Zr}$-Ce composite oxides suspensions under the fluorescent lamp irradiation was also shown in Fig. 7. The $\mathrm{Zr}-\mathrm{Ce}$ composite oxide with the composition of $\mathrm{Zr}_{0.5} \mathrm{Ce}_{0.5} \mathrm{O}_{2}$ showed higher ability to decompose the surfactant and the cooking oil than titanium oxide. The COD values of the surfactant decreased $25 \%$ and those of a cooking oil decreased almost $80 \%$ within 24 hours. It seems that these decomposition of organic substances is caused by the high oxygen storage/release capacity of $\mathrm{Zr}-\mathrm{Ce}$ composite oxides ${ }^{77}$. The oxygen storage/release of $\mathrm{Zr}-\mathrm{Ce}$ composite oxide seems to be caused by the absorption of visible light with the longer wavelength than $500 \mathrm{~nm}$

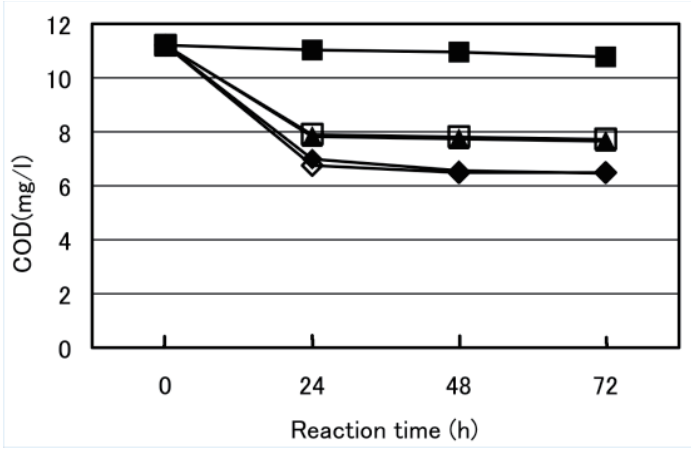

Fig. 6 Time dependences of COD in the surfactant and $\mathrm{Zr}-\mathrm{Ce}$ composite oxide suspensions under the fluorescent lamp irradiation.

$\mathrm{Zr} / \mathrm{Ce}$ molar ratio; $\square: 3 / 7, \boldsymbol{\Delta}: 4 / 6, \diamond: 5 / 5$,

$\mathbf{\square}$ : without oxides, $\diamond: \mathrm{TiO}_{2}$ for comparison 


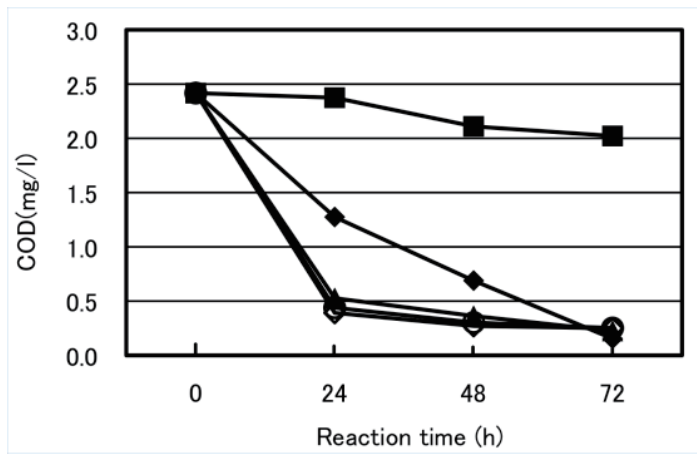

Fig. 7 Time dependence of COD in the cooking oil and $\mathrm{Zr}$-Ce composite oxide suspensions under the fluorescent lamp irradiation.

$\mathrm{Zr} /$ Ce molar ratio; $\bigcirc: 10 / 0, \diamond: 5 / 5, \mathbf{\Lambda}: 0 / 10$
$\mathbf{\square}$ : without oxides, $\diamond: \mathrm{TiO}_{2}$ for comparison

Finally, the whey protein solution was decomposed by $\mathrm{Zr}-\mathrm{Ce}$ composite oxides under the fluorescent lamp irradiation. In Fig. 8, the vertical axis shows the whey protein concentration deduced from the COD values. The composite oxide with the composition of $\mathrm{Zr}_{03} \mathrm{Ce}_{0.7} \mathrm{O}_{2}$ showed the higher ability to decompose whey protein, compared with the other composite oxides. The ability of the $\mathrm{Zr}_{0.3} \mathrm{Ce}_{0.7} \mathrm{O}_{2}$ composite oxides in adsorption is important for the decomposition of whey protein because the visible ray is hard to penetrate the cloudy whey protein solution.

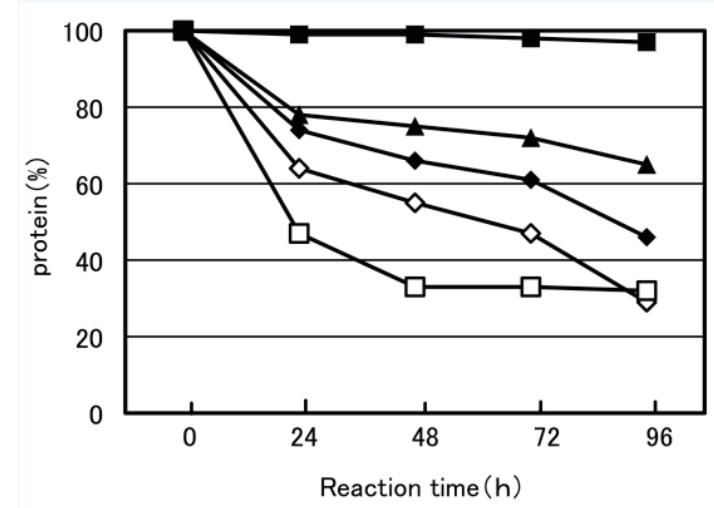

Fig. 8 Time dependence of the whey protein composition in the $\mathrm{Zr}-\mathrm{Ce}$ composite oxide suspensions under the fluorescent lamp irradiation.

$\mathrm{Zr} / \mathrm{Ce}$ molar ratio; $\square: 3 / 7, \diamond: 5 / 5, \boldsymbol{\Delta}: 0 / 10$,

$\mathbf{\square}$ : without oxides, $\diamond: \mathrm{TiO}_{2}$ for comparison

\section{CONCLUSION}

We synthesized the granular shaped $\mathrm{Zr}-\mathrm{Ce}$ composite oxides, of which diameter was in the range from 2 to 4 $\mu \mathrm{m}$. The sample with the nominal composition of $\mathrm{Zr}_{0.5} \mathrm{Ce}_{0.5} \mathrm{O}_{2}$ calcined at $400^{\circ} \mathrm{C}$ show optical absorption in the wavelength range shorter than $600 \mathrm{~nm}$. The photocatalytic ability under the visible ray and the adsorption activity of $\mathrm{Zr}-\mathrm{Ce}$ composite oxide crystals were confirmed. Also, $\mathrm{Zr}_{0.5} \mathrm{Ce}_{0.5} \mathrm{O}_{2}$ heat-treated at $400^{\circ} \mathrm{C}$ showed the high ability to decompose a surfactant and a cooking oil in the aqueous solution. In addition, whey protein in cloudy solution was well decomposed because of the high adsorption ability of $\mathrm{Zr}_{0.3} \mathrm{Ce}_{0.7} \mathrm{O}_{2}$ calcined at $400^{\circ} \mathrm{C}$.

\section{REFERENCES}

[1] H. Hidaka, N. Watanabe, T. Oyama, and S. Horikoshi, Materials Integration, 17, 26-29 (2004).

[2] A. Suda, K. Yamakawa, Y. Ukyo, T. Sasaki, and H. Sobukawa, J. Ceram. Soc. Jpn., 112, 581-585 (2004).

[3] T. Masui, K. Fujiwara, Y. Peng, T. Sakata, K. Machida, and H. Mori, G.Adachi, J. Alloys Comp., 269, 116-122 (1995).

[4] E. Tani, M. Yoshimura, and S. Munemiya, J. Ceram. Soc. Jpn., 90, 195-201 (1982).

[5] JCPDS No.38-1436.

[6] JCPDS No.38-14378.

[7] M. Sugiura, M. Ozawa, A. Suda, T. Suzuki, and T. Kanazawa, Bull. Chem. Soc. Jpn., 78, 752-767 (2005).

(Received December 23, 2008; Accepted June 24, 2009) 